\section{Optimizing Sweetpotato Production for Fresh and Processing Markets through Plant Spacing and Planting-harvest Time}

\author{
Ramón A. Arancibia ${ }^{1,4}$, Cody D. Smith ${ }^{2}$, Don R. LaBonte ${ }^{2}$, \\ Jeffrey L. Main ${ }^{1}$, Tara P. Smith ${ }^{3}$, and Arthur Q. Villordon ${ }^{3}$
}

ADDITIONAL INDEX WORDs. bulk harvest, cost-benefit, cultural practices, Ipomoea batatas, marginal analysis

Summary. Consumption of sweetpotato (Ipomoea batatas) has increased in the past decade in part because of its nutritional and health attributes, and because of the availability and convenience of processed products. The sweetpotato processing industry is expanding and supplying more sweetpotato products than ever before. Unlike the medium-sized roots (U.S. no.1) preferred for fresh market, large (jumbo) roots is accepted and in certain cases desired by the processing industry, and overall yield is preferred over strict sizing requirements and aesthetic appeal. Therefore, this study investigated the yield increase and grade proportions in response to plant spacing and extension of the growing period to improve profitability of the production system. Experiments with 'Beauregard' and 'Evangeline' sweetpotato were conducted in Mississippi and Louisiana during 2010 and 2011. Treatments consisted of a combination of early and late planting date and delay in harvest, in-row plant spacing, and row width. Yield increase was inconsistent with delaying harvest and appears to depend on environmental conditions at harvest late in the season. Marketable yield was consistently greater in early plantings than late plantings. Yield of U.S. no.1 grade was unaffected by delaying harvest regardless of planting date. Delaying harvest in early plantings contributed to increase jumbo-sized roots and marketable yield. The economic assessment of delaying harvest in early plantings indicated a gain in net benefit either when hand harvested for fresh market or field run bulk harvested for processing. Row width and in-row plant spacing had only a marginal effect on yield of canner grade (smallsized roots). The economic assessment of changing plant density indicated no gain in net benefit, which indicates that choice of plant density can depend on other factors.

S weetpotatoes are grown in the United States primarily for the fresh market, which demands attractive medium-sized roots of uniform shapes that are free from

This article is based on work supported by the National Institute of Food and Agriculture, U.S. Department of Agriculture, under project no. MIS145060, the Mississippi Agriculture and Forest Experiment Station, the Louisiana State University Agricultural Center, the Mississippi Sweet Potato Council, and the Louisiana Sweet Potato Advertising and Development Commission.

Mention of a trademark, proprietary product, method, or vendor does not imply endorsement by Mississippi State University and does not imply its approval to the exclusion of other products or vendors that also may be suitable.

${ }^{1}$ Pontotoc Ridge-Flatwoods Branch Experiment Station, North Mississippi Research and Extension Center, Mississippi State University, 8320 Highway 15 South, Pontotoc, MS 38863

${ }^{2}$ Louisiana Agricultural Experiment Station, Louisiana State University Agricultural Center, School of Plant, Environmental, and Soil Sciences, 104 Sturgis Hall, Baton Rouge, LA 70803

${ }^{3}$ Sweet Potato Research Station, Louisiana State University Agricultural Center, P.O. Box 120, Chase, LA 71324

${ }^{4}$ Corresponding author. E-mail: raa66@msstate.edu. blemishes. This class brings the highest price. In contrast, the processing sector can use storage roots of all sizes, but in the sweetpotato fry industry, they prefer large roots because the recovery is greater (longer and more consistent fry length than with medium-sized roots). In addition, shape is not as critical as for fresh market, and total yield within their quality expectations is more important than the proportion of U.S. no.l (medium size). The U.S standards for grades of sweetpotato are U.S. Extra no.l with roots $1-3 / 4$ to $3-1 / 4$ inches diameter, 3 to 9 inches long that are less than $18 \mathrm{oz}$; U.S. no.1 with roots $1-3 / 4$ to $3-1 / 2$ inches diameter, 3 to 9 inches long that are less than 20 oz; U.S. no.l Petite (or canner) with roots $1-1 / 2$ to $2-1 / 4$ inches diameter and 3 to 7 inches long; and U.S. no. 2 consisting of roots larger than 1-1/2 inches diameter, unless otherwise specified, with a maximum weight of $32 \mathrm{oz}$ [U.S. Department of Agriculture (USDA), 2005]. The commercial grade known as jumbo is larger than U.S. no.l in diameter and/or length, and falls in the U.S. no.2 category. The market for jumbo and canner grades is primarily the processing industry. Because of the differences in size and quality standards for the processing industry vs. the fresh market, diverse production strategies may be necessary to optimize returns.

In the United States, sweetpotato is produced mainly in the southern states and the west coast with over 130,000 acres planted in 2012 (USDA, 2013a). Mississippi and Louisiana ranked second and fourth in the nation for sweetpotato acreage with 24,000 acres and 10,000 acres planted in 2012, respectively. In addition, Mississippi and Louisiana ranked third and fourth, respectively, in the nation for sweetpotato crop value with over $\$ 62.6$ million and $\$ 33.3$ million in gross farm value in 2012 (USDA, $2013 \mathrm{~b}$ ). The acreage and production of sweetpotato could increase even further because demand and per capita consumption are increasing (46\% in the past decade) mainly due to two factors: the perceived nutritional and health attributes, and the availability and convenience of value-added processed products (Nalley et al., 2005; USDA, 2011; Woolfe, 1992).

Sweetpotato growers are quickly adjusting to processor's demands to

\begin{tabular}{llll}
\hline $\begin{array}{l}\text { Units } \\
\text { To convert U.S. to SI, } \\
\text { multiply by }\end{array}$ & U.S. unit & SI unit & $\begin{array}{l}\text { To convert SI to U.S., } \\
\text { multiply by }\end{array}$ \\
\hline 0.4047 & $\mathrm{acre}(\mathrm{s})$ & $\mathrm{ha}$ & 2.4711 \\
45.3592 & $\mathrm{cwt}$ & $\mathrm{kg}$ & 0.0220 \\
112.0851 & $\mathrm{cwt} / \mathrm{acre}$ & $\mathrm{kg} \cdot \mathrm{ha}^{-1}$ & 0.0089 \\
0.3048 & $\mathrm{ft}$ & $\mathrm{m}$ & 3.2808 \\
2.54 & inch $(\mathrm{es})$ & $\mathrm{cm}$ & 0.3937 \\
0.4536 & $\mathrm{lb}$ & $\mathrm{kg}$ & 2.2046 \\
1.1209 & $\mathrm{lb} / \mathrm{acre}$ & $\mathrm{kg} \cdot \mathrm{ha}^{-1}$ & 0.8922 \\
28.3495 & $\mathrm{Oz}$ & $\mathrm{g}$ & 0.0353 \\
$\left({ }^{\circ} \mathrm{F}-32\right) \div 1.8$ & ${ }^{\circ} \mathrm{F}$ & ${ }^{\circ} \mathrm{C}$ & $\left({ }^{\circ} \mathrm{C} \times 1.8\right)+32$
\end{tabular}


make the crop more widely available. The main objective of fresh market growers is U.S. no.l, but they supply processors with large roots for processed products to improve profitability. Therefore, an approach to increase root yield must be examined to satisfy the greater processing demand while maintaining yield of U.S. no.l grade for fresh market. In contrast, some producers are targeting the processing sector exclusively with field-run bulk-harvest contracts; however, to be profitable, yield must increase and production costs must be reduced considerably in comparison with production intended for the fresh market. Achieving a higher total yield is critical given the lower price paid by the processors for field-run harvest. Therefore, this study focused on determining yield increases and changes in grade proportions in response to plant spacing and extension of the growing period to improve profitability of the production system intended for either fresh market or the processing industry.

Sweetpotato producers targeting fresh market venues strive to achieve a large percentage of U.S. no.l grade roots, while minimizing small and jumbo grade roots. Growers are challenged to time-harvesting operations to reduce the number of unwanted roots and maximize marketing potential and profit. Growing roots to increase larger roots and tonnage while maintaining U.S. no.l yield can create a larger window of success considering that the roots essentially can grow as long as environmental conditions are favorable. In addition, our assumption that a delay in harvest reduces U.S. no.l yield may be incorrect and producers targeting the fresh market may realize a yield gain by increasing jumbo yield. There is a need to examine different planting and harvest dates, plant spacing, and row widths to determine the best combination to increase the number of large roots and overall tonnage while maintaining U.S. no.l yield.

It is generally thought that high plant densities result in small storage roots, and as plant density decreases, the number of large roots increases (Rubatzky and Yamaguchi, 1997). Most growers use row widths ranging from 38 to 42 inches to produce sweetpotato in the United States. However, the difference, if any, between various row widths has not been evaluated with current commercial varieties. Extension publications from the main sweetpotato production states have no specific row width recommendations except California where a doublerow system on 80 -inch beds is used to accommodate the drip irrigation system (Boudreaux, 2009; Schultheis et al., 2005; Stoddard et al., 2013; Thompson et al., 2002). Row width of $3-1 / 5$ to $4 \mathrm{ft}$ is recommended in Alabama (Kemble et al., 2006). Inrow plant spacing recommendations are available in all states, but vary somewhat among states and varieties, and range from 8 to 16 inches. Inrow plant spacing has been reported to influence yield of U.S. no.1; however, varieties responded differently to spacing and planting-harvest time (Mulkey et al., 1994; Schultheis et al., 1999). In addition, the study in North Carolina reported that 'Beauregard' planted at 15 or $23 \mathrm{~cm}$ increased net economic value compared with wider in-row spacing (Schultheis et al., 1999). To our knowledge, in-row plant spacing has not been evaluated at different row widths with current commercial varieties.

The objective of this study is to determine the importance of planting and harvest dates, and plant spacing in 'Beauregard' and 'Evangeline' sweetpotato to improve yields and economic benefit. Most of the research in the United States with varieties destined for food consumption has been directed to optimize U.S. no.l root grade toward the fresh market sector. Consequently, studies with the objective of increasing total tonnage of root grades destined for processing are lacking. Furthermore, no information is available in the United States about the response to in-row plant spacing and row width combinations at different planting-harvest dates to increase tonnage and determine changes in the proportion of root grades. Storage root grades differ in value and therefore influence gross income and profitability.

\section{Materials and methods}

Field research was conducted at the Pontotoc Ridge-Flatwoods Experiment Station-Mississippi State University [Pontotoc, MS (lat. $42^{\circ} 1^{\prime} \mathrm{N}$, long. $\left.\left.93^{\circ} 38^{\prime} \mathrm{W}\right)\right]$ and at the Louisiana State University Agricultural Center-Sweet Potato Research
Station [Chase, LA (lat. $32^{\circ} 6^{\prime} \mathrm{N}$, long. $\left.\left.91^{\circ} 42^{\prime} \mathrm{W}\right)\right]$ in Summer 2010 and 2011. In Mississippi, the soil type was a Falkner silt loam (fine-silty, mixed, thermic Typic Ochraqualfs) and in Louisiana it was fine-silty, mixed, active, thermic Typic Glossaqualfs. 'Beauregard' and 'Evangeline' sweetpotato, G-1 (generation 1) in Mississippi and G-0 in Louisiana from the foundation seed stock in each state were used. 'Beauregard' was selected because it is the main variety used in Louisiana and Mississippi. 'Evangeline' was recently released at the time of this investigation and information about plant cultural practices needed to be defined. Field preparation activities, including fertilizer rates, herbicide, and insecticide applications, were similar in each year for each state (Boudreaux, 2012; Thompson et al., 2002). There was no supplemental irrigation supplied in Mississippi, but in Louisiana supplemental overhead irrigation was supplied with a traveling irrigation sprinkler if a rainfall event did not occur. In-season supplemental irrigation was based on soil moisture of $30 \%$ to $50 \%$ of field capacity at 6 -inch depth. For the soil type used in the study, 16\% volumetric water content represents $50 \%$ of field capacity.

In Mississippi, the experimental design for each year was a split-split plot with harvest date [days after planting (DAP)] as the main effect (plot), in-row plant spacing as subplot and variety as sub-subplot with four replications. Each experimental unit (sub-subplot) consisted of three $20-\mathrm{ft}$ rows and the center row was harvested for evaluation. Plant spacing was 40 inches between rows and there were three in-row planting distances: 12,16 , and 20 inches. Planting was on 15 June 2010 and 9 June 2011. Storage roots were harvested on 13 Oct. 2010 (120 DAP) and 2 Nov. 2010 (140 DAP). To avoid cold temperatures by the end of the season and since yields were not different between both harvest dates in 2010 , harvest was earlier in 2011: 16 Sept. 2011 (99 DAP) and 17 Oct. 2011 (130 DAP). Plots were harvested using a single-row mechanical chain harvester. After harvest, storage roots were cured for $7 \mathrm{~d}\left(85{ }^{\circ} \mathrm{F}\right.$ and $80 \%$ to $85 \%$ relative humidity) and stored until evaluation. After 2 months, storage roots were classified using a modification 
of the U.S. standards for grades of sweetpotatoes (USDA, 2005). U.S. no.l grade consisted of roots 2 to 3 $1 / 2$ inches diameter and 3 to 9 inches long, canner grade consisted of roots $1-1 / 2$ to 2 inches diameter and 3 to 7 inches long, and jumbo grade was anything larger than U.S. no.l.

In Louisiana, treatments consisted of a combination of two planting dates (early and late) and two harvest dates (early and late). The planting-harvest combinations were as follows: EE [early planting ( 1 June 2010 and 7 June 2011) with early harvest (4 Oct. 2010 and 10 Oct. 2011)], EL [early planting with late harvest (19 Oct. 2010 and 25 Oct. 2011)], LE [late planting (30 June 2010 and 8 July 2011) with early harvest (2 Nov. 2010 and 10 Nov. 2011)], and LL [late planting with late harvest (17 Nov. 2010 and 25 Nov. 2011)]. Treatments were replicated four times. In addition, two row widths (38 and 42 inches) and two inrow plant spacing (12 and 16 inches) were evaluated. The two varieties were planted in two-row plots $(30 \mathrm{ft}$ long) with 10 -ft alleys between plots. For each treatment combination, one row of each plot was harvested at 125 DAP (early harvest) and the remaining row was harvested at 140 DAP (late harvest) with a single-row mechanical chain harvester. After harvesting, roots were separated into U.S. no.l, jumbo, or canner grades as described above and weighed.

Data from both locations were analyzed similarly. Yield for each grade, the combined yield of U.S. no.1 + jumbo grades and total marketable yield (all three grades) as well as the proportion of U.S. no.l and U.S. no.l + jumbo grades were determined and compared among treatments. The proportion of U.S. no.1 grade and the combination of U.S. no. $1+$ jumbo grades are presented as percentages, but the data were transformed [arcsin (square root)] for statistical analysis to stabilize the variances. Statistical analyses were conducted with SAS statistical software (version 9.2 for Windows; SAS Institute, Cary, NC). Analysis of variance was performed by Proc Mixed and differences among means were adjusted by Tukey's multiple range test $(P \leq 0.05)$. Data are presented by variety and also by year due to interaction.
Cost-benefit and marginal analyses were performed for each variety each year and location to evaluate the gain in net economic benefit and the marginal rate of return of the alternative practice/technologies (International Maize and Wheat Improvement Center, 1988). The change (gain/loss) in net benefit (change in gross benefit change in costs that varied) and the changes in costs incurred by modifying plant density and delaying harvest time was based on current sweetpotato prices and estimated costs for field operations in Mississippi for 2013 (Hood et al., 2012). The change in gross benefit was determined by the difference in total gross benefit between the standard practice and the alternative practice/technology (e.g., early and late harvest). Total gross benefit for each practice/treatment was calculated by the addition of the individual gross benefits (yield $\times$ price) from each grade. Prices for sweetpotato grades after subtracting, cleaning, packing, and marketing costs were $\$ 12$ per 50 -lb bushel (bu) for U.S. no.1, $\$ 6.5$ and $\$ 3.5$ per hundredweight (cwt) for jumbo and canner, respectively, and $\$ 15 / \mathrm{cwt}$ for fieldrun U.S. no.1 + jumbo. The change in costs that varied was determined by the difference in the costs that varied between the standard practice and the alternative practice/technology. Costs that varied when changing plant density were estimated based on a linear relationship with the estimated planting costs $(\$ 29$ per 1000 plants and $\$ 98.13 /$ acre for the use of the planter, labor, and miscellaneous planting costs) for 1 acre planted at $42 \times 16$ inches plant spacing, which is the most common plant spacing in Mississippi (Hood et al., 2012). Costs that varied when delaying harvest were also estimated based on a linear relationship with the estimated harvest costs [ $\$ 2.40 / \mathrm{bu}$ for hand harvest, hauling, and storage of a $330 \mathrm{bu} /$ acre sweetpotato yield for fresh market (Hood et al., 2012), and $\$ 2.44 / \mathrm{cwt}$ for mechanical bulk harvest, hauling, and storage for processing of a $500 \mathrm{cwt} / \mathrm{acre}$ potato (Solanum tuberosum) yield (Carlson et al., 2008)]. The marginal rate of return was determined by the ratio between the change in net benefit and the change in costs that varied, and indicates the gain/loss in net benefit obtained per additional dollar invested in the alternative practice/technology.

\section{Results}

In Mississippi, sweetpotato yield was similar in 2010 and 2011 , but marketable yield was higher in 'Beauregard' than 'Evangeline' both years with 616 over $520 \mathrm{bu} /$ acre and 596 over $498 \mathrm{bu} /$ acre in 2010 and 2011, respectively (Tables 1 and 2 ). 'Beauregard' U.S. no.l and canner yields in 2010 , and jumbo and canner yields in 2011 were higher than 'Evangeline'. Consequently, the combination of U.S. no.l + jumbo grades and total marketable yields were higher by $30 \%$ and $18 \%$ in 2010 and by $16 \%$ and $20 \%$ in 2011 , respectively. In addition, the proportion of U.S. no.l and the combination of U.S. no.l + jumbo grades of 'Beauregard' sweetpotato were larger than 'Evangeline' in 2010 , but not in 2011. In Louisiana, yields were different between years and varieties (Table 3 ). Variety interactions were not significant at $P \leq$ 0.05 , but interactions occurred between years for canners and marketable yield in 'Beauregard', and for U.S. no.l, U.S. no.l + jumbo, and marketable yield in 'Evangeline'. 'Beauregard' marketable yield was 1446 and $865 \mathrm{bu} / \mathrm{acre}$ for 2010 and 2011, respectively, and 'Evangeline marketable yield was 865 and 699 bu/acre for 2010 and 2011, respectively (data not presented).

Harvest Delay. Delaying harvest from 120 to 140 DAP in Mississippi had no effect on any yield category in 2010; consequently, data were pooled together for analysis (Table 1). There were no differences detected in yield of U.S. no.l and jumbo grades due to in-row plant spacing in both varieties. There was interaction between variety and plant spacing for the canner grade in 2010 , so spacing analysis was conducted separately for each variety. Canner yield was higher at 12 inches in-row spacing in 'Beauregard' sweetpotato, but not in Evangeline. Although marketable yield was not different among the in-row spacing tested for each variety in 2010 (Table 1), there was no interaction and the combined yields resulted in higher yield at 12 inches than 16 and 20 inches in-row spacing (data not shown). In 2011, there were no differences among inrow plant spacing, but yield differences due to harvest time were detected as well as harvest time by variety 
Table 1. Sweetpotato yield in response to in-row plant spacing (harvest time combined) without irrigation at Pontotoc, MS, in 2010 .

\begin{tabular}{|c|c|c|c|c|c|c|c|c|}
\hline Variety & $\begin{array}{c}\text { In-row spacing } \\
\text { (inches) }^{z}\end{array}$ & $\begin{array}{l}\text { U.S. no.l } \\
{\text { (bu/acre })^{\mathrm{y}}}^{\text {(but }}\end{array}$ & $\begin{array}{c}\text { Jumbo } \\
\text { (bu/acre) }\end{array}$ & $\begin{array}{c}\text { U.S. no.1 + } \\
\text { Jumbo (bu/acre) }\end{array}$ & $\begin{array}{c}\text { Canner } \\
\text { (bu/acre) }\end{array}$ & $\begin{array}{c}\text { Marketable } \\
\text { (bu/acre) }\end{array}$ & $\begin{array}{c}\text { U.S. } \\
\text { no.1 (\%) }\end{array}$ & $\begin{array}{l}\text { U.S. no.1 }+ \\
\text { Jumbo (\%) }\end{array}$ \\
\hline \multirow[t]{5}{*}{ Beauregard } & 12 & 386 & 189 & 575 & $120 a^{x}$ & 695 & 56 & 83 \\
\hline & 16 & 354 & 135 & 489 & $70 \mathrm{~b}$ & 559 & 64 & 87 \\
\hline & 20 & 363 & 170 & 533 & $60 \mathrm{~b}$ & 593 & 62 & 90 \\
\hline & Significance & NS & NS & NS & $* * *$ & NS & NS & NS \\
\hline & Correlation $(r)$ & & & & -0.67 & & & \\
\hline & 20 & 257 & 149 & 406 & 104 & 510 & 53 & 78 \\
\hline & Significance & NS & NS & NS & NS & NS & NS & NS \\
\hline Beauregard & & 368 & 165 & 532 & 83 & 616 & 61 & 87 \\
\hline Evangeline & & 258 & 153 & 410 & 110 & 520 & 51 & 77 \\
\hline Significance & & $* * *$ & NS & $* * *$ & ** & ** & $* *$ & $* * *$ \\
\hline
\end{tabular}

${ }^{\mathrm{z}} 1$ inch $=2.54 \mathrm{~cm}$.

y.S. no. 1 roots are 2 to $3-1 / 2$ inches diameter, 3 to 9 inches long, straight, uniform roots free of blemishes; canner roots are $1-1 / 2$ to 2 inches diameter, 3 to 7 inches long; jumbo roots are larger than U.S. no.l; one $50-\mathrm{lb}(22.7 \mathrm{~kg})$ bushel $/ \mathrm{acre}=56.0426 \mathrm{~kg} \cdot \mathrm{ha}^{-1}$.

${ }^{x}$ Means within columns followed by different letters are significantly different from each other by Tukey's multiple range test at $P \leq 0.05$.

NS, **,$* *$ Nonsignificant and significant at $P \leq 0.01$ and 0.001 , respectively.

Table 2. Sweetpotato yields in response to delayed harvest (in-row plant spacing combined) without irrigation at Pontotoc, MS, in 2011.

\begin{tabular}{|c|c|c|c|c|c|c|c|c|}
\hline Variety & $\begin{array}{l}\text { Planting-harvest } \\
\text { time }(\mathrm{DAP})^{\mathrm{z}}\end{array}$ & $\begin{array}{l}\text { U.S. no.1 } \\
{\text { (bu/acre })^{\mathrm{y}}}\end{array}$ & $\begin{array}{l}\text { Jumbo } \\
\text { (bu/acre) }\end{array}$ & $\begin{array}{c}\text { U.S. no.1 + } \\
\text { Jumbo (bu/acre) }\end{array}$ & $\begin{array}{l}\text { Canner } \\
\text { (bu/acre) }\end{array}$ & $\begin{array}{c}\text { Marketable } \\
\text { (bu/acre) }\end{array}$ & $\begin{array}{c}\text { U.S. } \\
\text { no.1 }(\%)\end{array}$ & $\begin{array}{c}\text { U.S. no.1 + } \\
\text { Jumbo (\%) }\end{array}$ \\
\hline \multirow[t]{2}{*}{ Beauregard } & 99 & 262 & 93 & 356 & 89 & 445 & 62 & 70 \\
\hline & Significance & NS & $* * *$ & ** & * & $* * *$ & $* * *$ & NS \\
\hline \multirow[t]{2}{*}{ Evangeline } & 99 & 244 & 98 & 342 & 96 & 438 & 59 & 68 \\
\hline & 130 & 285 & 221 & 507 & 110 & 617 & 46 & 74 \\
\hline Evangeline & & 252 & 145 & 397 & 101 & 498 & 54 & 70 \\
\hline Significance & & NS & * & * & * & $* *$ & NS & NS \\
\hline
\end{tabular}

${ }^{z}$ Planting-harvest time: Planting date was 9 June 2011; harvest dates were 16 Sept. 2011 and 17 Oct. 2011 [99 and $130 \mathrm{~d}$ after planting (DAP), respectively].

U.S. no. 1 roots are 2 to $3-1 / 2$ inches diameter, 3 to 9 inches long, straight, uniform roots free of blemishes; canner roots are $1-1 / 2$ to 2 inches diameter, 3 to 7 inches long; jumbo roots are larger than U.S. no.l; $\mathrm{l}$ inch $=2.54 \mathrm{~cm}$, one $50-\mathrm{lb}(22.7 \mathrm{~kg})$ bushel $/ \mathrm{acre}=56.0426 \mathrm{~kg} \cdot \mathrm{ha}^{-1}$.

Ns, ${ }^{*},{ }^{*},{ }^{* *}$ Nonsignificant and significant at $P \leq 0.05,0.01$, and 0.001 , respectively.

interactions (Table 2). In 'Beauregard', yield of jumbo and canner grades, but not of U.S. no.l grade, increased $289 \%$ and $144 \%$, respectively, from 99 to $130 \mathrm{DAP}$. In 'Evangeline' sweetpotato, only yield of jumbo grade increased by $126 \%$ from 99 to $130 \mathrm{DAP}$. Consequently, U.S. no.1 + jumbo grades increased by $86 \%$ and $48 \%$ from 99 to 130 DAP in 'Beauregard' and 'Evangeline', respectively, but total marketable yield increased by $97 \%$ only in 'Beauregard' sweetpotato. In contrast, the yield proportion of U.S. no.1 grade was reduced in both varieties (Table 2 ).

In Louisiana, yields were different among planting and harvest date combination (EE, EL, LE, and LL) in both years (Table 3 ). In general, yield of early plantings were higher than late plantings with 'Beauregard' both years, but only in 2011 with
'Evangeline'. Early planting in 'Beauregard' increased U.S. no.1 yields by $21 \%$ and $115 \%$ in 2010 and 2011 , respectively, regardless of the harvest date. For 'Evangeline', differences were found only in 2011 where EL U.S. no.1 yield was $38 \%$ and $170 \%$ higher than EE and the late plantings (LE and LL), respectively. In 2010, jumbo yield of 'Beauregard' increased by $128 \%$ in EL over the next plantingharvest combination (EE). In 2011 , jumbo yield of EL was not different from EE, but EL was 195\% higher than the late planting yields (LE and LL). For 'Evangeline', EL jumbo yield was higher than EE and the late plantings at least by $164 \%$ in 2010 , and in 2011, early plantings were 6.8fold higher than late plantings regardless of harvest time. For 'Beauregard', yield of U.S. no.1 + jumbo in EL was the same as $\mathrm{EE}$ in 2010 , but $47 \%$ higher than the late planting yields. In 2011 , yield of U.S. no.1 + jumbo in early plantings was $118 \%$ higher than late plantings regardless of harvest time. For 'Evangeline', EL was at least 20\% higher than EE and the late plantings in 2010, but in 2011, EL was $32 \%$ higher than EE and at least $195 \%$ higher than the late plantings. In contrast, 'Beauregard' canner yields were increased by $75 \%$ in the late plantings in 2010 , but were inconsistent in 2011. For 'Evangeline', late planting canners were also higher than early plantings by $63 \%$ in 2010 , but in 2011 , EL was 39\% higher than EE and $156 \%$ higher than LL. 'Beauregard' marketable yields were the same among the various planting and harvest dates in 2010, but in 2011 , EL was 25\% higher than EE and $78 \%$ higher than the late planting dates. For Evangeline', EL marketable 
Table 3. Sweetpotato yield in response to planting-harvest time (row width and in-row spacing combined) with supplemental sprinkler irrigation at Chase, LA, in 2010 and 2011.

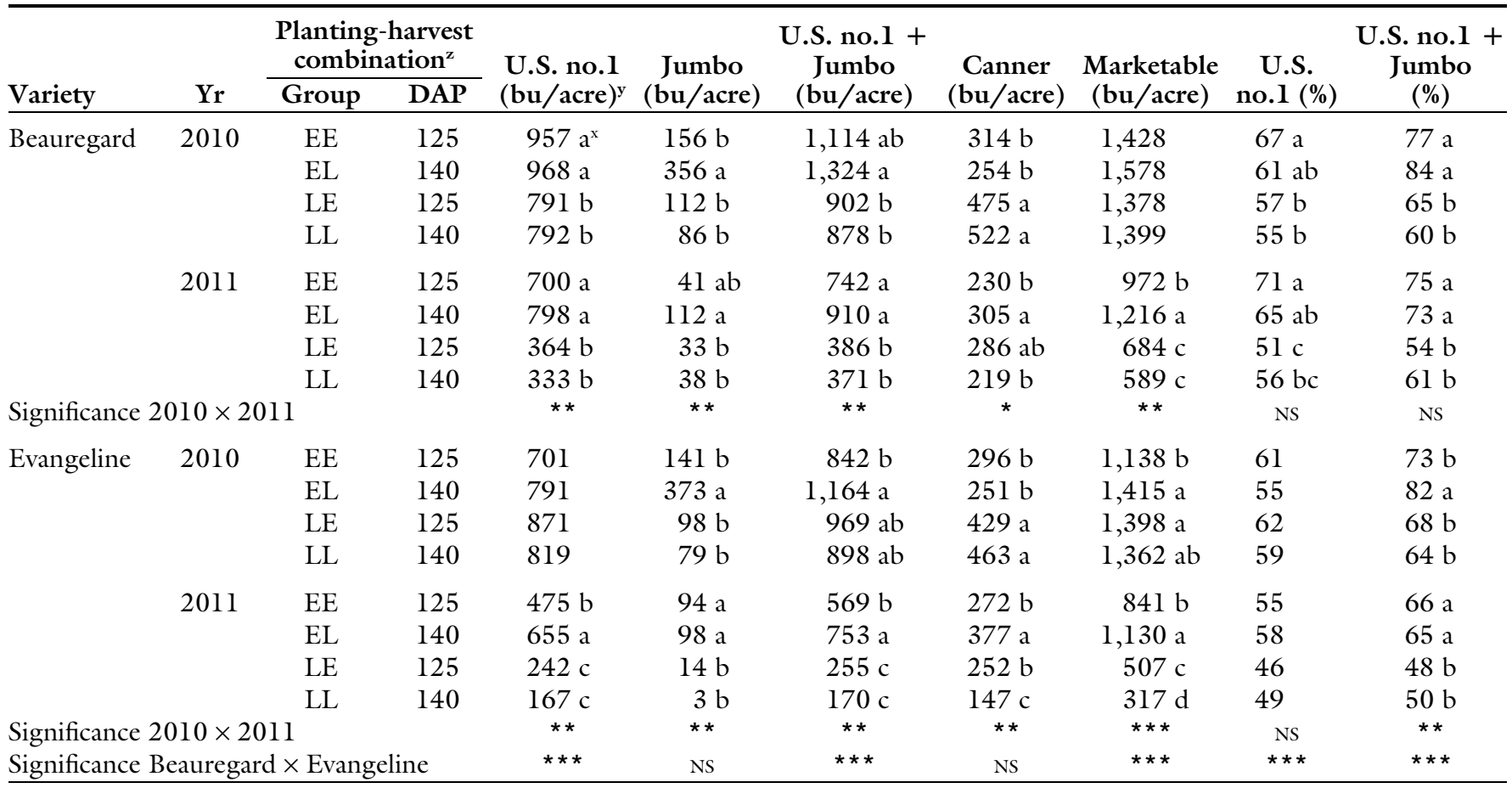

${ }^{2} \mathrm{EE}=$ early planting (1 June 2010, 7 June 2011), early harvest (4 Oct. 2010, 10 Oct. 2011); EL = early planting, late harvest (19 Oct. 2010 , 25 Oct. 2011 ); LE = late planting (30 June 2010, 8 July 2011), early harvest ( 2 Nov. 2010, 10 Nov. 2011); and LL = late planting, late harvest (17 Nov. 2010,25 Nov. 2011$)$; DAP = days after planting. 'U.S. no. 1 roots are 2 to $3-1 / 2$ inches diameter, 3 to 9 inches long, straight, uniform roots free of blemishes; canner roots are $1-1 / 2$ to 2 inches diameter, 3 to 7 inches long; jumbo roots are larger than U.S. no.1; 1 inch $=2.54 \mathrm{~cm}$, one $50-\mathrm{lb}(22.7 \mathrm{~kg})$ bushel $/ \mathrm{acre}=56.0426 \mathrm{~kg} \cdot \mathrm{ha}^{-1}$.

${ }^{x}$ Means within columns followed by different letters are significantly different from each other by Tukey's multiple range test at $P \leq 0.05$.

NS, ${ }^{*},{ }^{*},{ }^{* *}$ Nonsignificant and significant at $P \leq 0.05,0.01$, and 0.001 , respectively.

yield in 2010 was $24 \%$ higher than $\mathrm{EE}$, but similar to the late plantings. However, in 2011 EL was $34 \%$, $123 \%$, and $256 \%$ higher than EE, LE, and LL, respectively. The proportion of 'Beauregard' U.S. no.1 as a fraction of the total marketable yield in EE only was larger than the late plantings both years; however, the proportion of U.S. no. $1+$ jumbo for both early plantings was larger than the late plantings regardless of harvest time both years. For 'Evangeline, the proportions of U.S. no.l were the same for all planting-harvest combinations both years. In contrast, the proportion of U.S. no.1+ jumbo for EL was larger than all other treatments in 2010 and the proportions of both early plantings were larger than the late plantings in 2011 (Table 3 ).

Plant Density. Yields were also analyzed according to in-row plant spacing (12 and 16 inches) for yield by grade for each variety (Table 4 ). Differences in yield between both inrow spacing were found only in canner grades. In 2010, 'Beauregard' yielded $17 \%$ higher in the 12 -inch in-row spacing than the 16 inches.
No difference was found in 2011. For 'Evangeline', canner yields at 12 inches were $6 \%$ and $25 \%$ higher than 16 inches in 2010 and 2011 , respectively. The effects of in-row spacing on the proportions of U.S. no.l grade and U.S. no.1 + jumbo were inconsistent. In 2010, only the 'Beauregard' U.S. no.1 proportion was higher at 16 inches. In contrast, U.S. no.l and U.S. no.l + jumbo proportions of 'Evangeline' were increased at 16 inches in 2011. No other differences were found in either year. The effect of increasing row width from 38 to 42 inches on yield was also investigated by variety (Table 5 ). The only differences were found in 2010 with canner grade of both varieties. Canner yield was $28 \%$ and $35 \%$ higher for 'Beauregard' and 'Evangeline', respectively, in the 42 inches row width. No other grade and yield proportion was different in both years.

ECONOMIC ASSESSMENT. The costbenefit analysis of changing plant density resulted in no changes in the net benefit because U.S. no.1, jumbo, and marketable yields were not different among row width and in-row plant spacing (Tables 1,4 , and 5), and the variability in gross and net income were greater than the changes in costs that varied (data not presented). The cost-benefit and marginal analyses of delaying harvest time were conducted with the data from early plantings in Louisiana both years and the 2011 study in Mississippi because of the yields in the late plantings were mostly the same (Tables 2, 3, and 6). Overall, delaying harvest in early plantings increased yields and therefore increased gross income as well as costs that varied. Depending on the harvest system, hand harvest for fresh market or field-run bulk harvest for processing, changes in gross income ranged from $\$ 677$ to $\$ 2415$ per acre. Changes in costs that varied were consistently lower for bulk harvest and ranged from $36 \%$ to $71 \%$ of the corresponding hand harvest. The changes in net benefit due to delaying harvest were positive in all early plantings. In general, the gains in net benefit were higher for the bulkharvest system ranging from \$1034 to $\$ 2022$ per acre than the handharvest system, which ranged from $\$ 315$ to $\$ 1663$ per acre. This reduced 
Table 4. Sweetpotato yield in response to in-row plant spacing (row width and planting-harvest time combined) with supplemental sprinkler irrigation at Chase, LA, in 2010 and 2011.

\begin{tabular}{|c|c|c|c|c|c|c|c|c|c|}
\hline Variety & Yr & $\begin{array}{l}\text { In-row } \\
\text { spacing } \\
\text { (inches) }^{z}\end{array}$ & $\begin{array}{l}\text { U.S. no.1 } \\
{\text { (bu/acre })^{y}}^{\text {bu }}\end{array}$ & $\begin{array}{l}\text { Jumbo } \\
\text { (bu/acre) }\end{array}$ & $\begin{array}{c}\text { U.S. no.1 + } \\
\text { jumbo (bu/acre) }\end{array}$ & $\begin{array}{l}\text { Canner } \\
\text { (bu/acre) }\end{array}$ & $\begin{array}{c}\text { Marketable } \\
\text { (bu/acre) }\end{array}$ & $\begin{array}{c}\text { U.S. } \\
\text { no.1 } \\
(\%)\end{array}$ & $\begin{array}{c}\text { U.S. no.1 + } \\
\text { jumbo (\%) }\end{array}$ \\
\hline \multirow[t]{3}{*}{ Beauregard } & 2010 & 12 & 873 & 181 & 1,055 & 422 & 1,476 & 58 & 70 \\
\hline & Significance & & NS & NS & NS & * & NS & * & NS \\
\hline & 2011 & 12 & 533 & 54 & 587 & 277 & 864 & 60 & 65 \\
\hline \multirow[t]{5}{*}{ Evangeline } & 2010 & 12 & 818 & 170 & 988 & 371 & 1,359 & 59 & 71 \\
\hline & & 16 & 774 & 175 & 949 & 349 & 1,298 & 59 & 73 \\
\hline & Significance & & NS & NS & NS & * & NS & NS & NS \\
\hline & 2011 & 12 & 369 & 57 & 427 & 291 & 718 & 48 & 53 \\
\hline & & 16 & 400 & 47 & 447 & 233 & 680 & 57 & 62 \\
\hline
\end{tabular}

${ }^{\mathrm{z}} \mathrm{l}$ inch $=2.54 \mathrm{~cm}$.

${ }^{y}$ U.S. no. 1 roots are 2 to $3-1 / 2$ inches diameter, 3 to 9 inches long, straight, uniform roots free of blemishes; canner roots are $1-1 / 2$ to 2 inches diameter, 3 to 7 inches long; jumbo roots are larger than U.S. no.l; one $50-\mathrm{lb}(22.7 \mathrm{~kg})$ bushel $/ \mathrm{acre}=56.0426 \mathrm{~kg} \cdot \mathrm{ha}^{-1}$.

NS, ${ }^{*},{ }^{*},{ }^{* *}$ Nonsignificant and significant at $P \leq 0.05,0.01$, and 0.001 , respectively.

Table 5. Sweetpotato yield in response to row width (in-row spacing and planting-harvest time combined) with supplemental sprinkler irrigation at Chase, LA, in 2010 and 2011.

\begin{tabular}{|c|c|c|c|c|c|c|c|c|c|}
\hline Variety & Yr & $\begin{array}{c}\text { Row width } \\
\text { (inches) }^{z}\end{array}$ & $\begin{array}{l}\text { U.S. no.1 } \\
{\text { (bu/acre })^{\mathrm{y}}}\end{array}$ & $\begin{array}{l}\text { Jumbo } \\
\text { (bu/acre) }\end{array}$ & $\begin{array}{c}\text { U.S. no.1 + } \\
\text { jumbo (bu/acre) }\end{array}$ & $\begin{array}{l}\text { Canner } \\
\text { (bu/acre) }\end{array}$ & $\begin{array}{c}\text { Marketable } \\
\text { (bu/acre) }\end{array}$ & $\begin{array}{c}\text { U.S. } \\
\text { no.1 (\%) }\end{array}$ & $\begin{array}{l}\text { U.S. no. } 1+ \\
\text { jumbo }(\%)\end{array}$ \\
\hline \multirow[t]{4}{*}{ Beauregard } & 2010 & 38 & 841 & 172 & 1,013 & 343 & 1,356 & 60 & 72 \\
\hline & Significance & & NS & NS & NS & * & NS & NS & NS \\
\hline & 2011 & 38 & 517 & 57 & 568 & 243 & 817 & 60 & 65 \\
\hline & & 42 & 581 & 55 & 636 & 278 & 913 & 62 & 67 \\
\hline \multirow[t]{5}{*}{ Evangeline } & 2010 & 38 & 819 & 171 & 990 & 306 & 1,297 & 62 & 74 \\
\hline & & 42 & 772 & 174 & 947 & 413 & 1,360 & 57 & 69 \\
\hline & Significance & & NS & NS & NS & * & NS & NS & NS \\
\hline & 2011 & 38 & 358 & 57 & 415 & 257 & 672 & 48 & 54 \\
\hline & & 42 & 411 & 47 & 459 & 267 & 726 & 56 & 61 \\
\hline
\end{tabular}

${ }^{\mathrm{z}} 1 \mathrm{inch}=2.54 \mathrm{~cm}$.

y.S. no. 1 roots are 2 to $3-1 / 2$ inches diameter, 3 to 9 inches long, straight, uniform roots free of blemishes; canner roots are $1-1 / 2$ to 2 inches diameter, 3 to 7 inches long; jumbo roots are larger than U.S. no.l; one $50-\mathrm{lb}(22.7 \mathrm{~kg})$ bushel $/ \mathrm{acre}=56.0426 \mathrm{~kg} \cdot \mathrm{ha}^{-1}$.

$\mathrm{NS}$, * Nonsignificant and significant at $P \leq 0.05$, respectively.

gain in net benefit was reflected in the marginal rate of return. For bulk harvest the marginal rate of return was consistently 5.15 , but for the handharvest system varied from 0.50 to 2.40. In addition, the gains in net benefit and the marginal rate of return were reduced in Mississippi, and considering the longer time harvest was delayed, $31 \mathrm{~d}$ compared with $15 \mathrm{~d}$ in Louisiana, the gains and rate are comparatively lower.

\section{Discussion}

The yield response to planting and harvest combinations as well as the in-row plant spacing treatments in Mississippi and Louisiana were comparable and data are validated because the same varieties were used. In Mississippi, the late planting in combination with early and late harvest conducted in 2010 were comparable to the LE and LL planting-harvest combination in Louisiana (Tables 1 and 3 ). The lack of yield response to delayed harvest in the late plantings may be most likely due to cold temperatures late in the season. The planting-harvest combinations investigated in Mississippi in 2011 were comparable to the EE and EL planting- harvest combinations in Louisiana where yield increased with a delay in harvest under favorable temperature regimes (Tables 2 and 3 ). Although actual yields of 'Beauregard' were higher than 'Evangeline' in this study, the yield responses to the treatments were similar in both varieties and states. This may differ with other varieties and locations.

Harvest delay. Extending the growing period in sweetpotato allows the storage roots to grow larger resulting in increased tonnage of marketable roots (Tables 2 and 3 ). In most grade categories, the early planting date and 


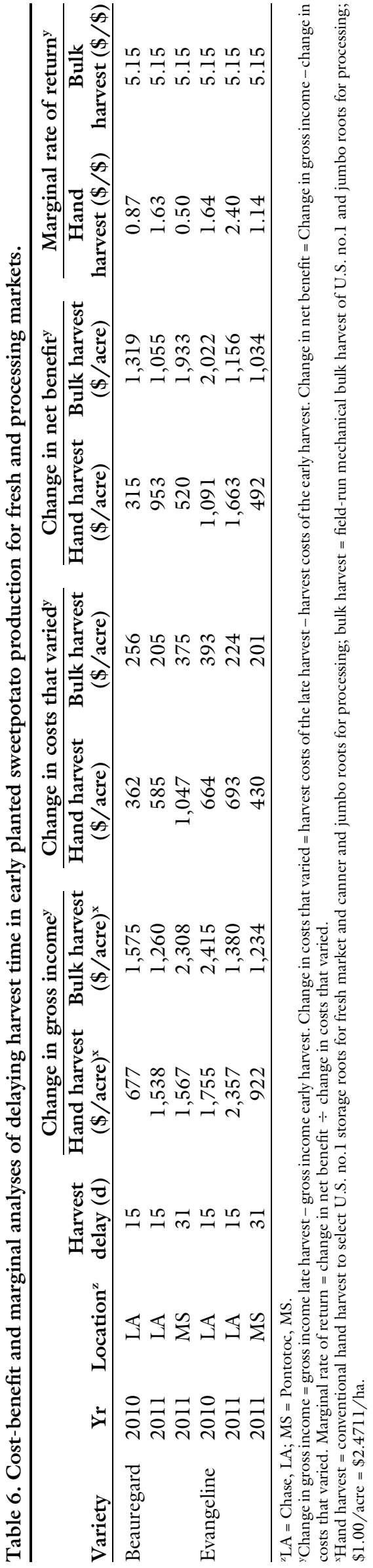

late harvest date combination was regarded as the best combination to maximize tonnage (Tables 2 and 3 ). Recent research suggests that it is extremely important to get transplants planted as early as possible during the growing season, but not until soil temperature is above $65^{\circ} \mathrm{F}$ (Villordon et al., 2010). Typically, anything planted in July in the southern U.S. region adjacent to the Gulf of Mexico does not perform as well as those planted before July, as high temperatures have been shown to reduce storage root formation (Ravi and Indira, 1999; Reddy et al., 2013). Delaying harvest is thought to achieve higher yield and more jumbo roots because sweetpotato is indeterminate and continues growing under adequate environmental conditions (Loebenstein and Thottappilly, 2009). In this study, the average increase in marketable yield in the early plantings when harvest was delayed 15 to $31 \mathrm{~d}$ ranged from 10 to 16 and 6 to $19 \mathrm{bu} / \mathrm{acre}$ per day for 'Beauregard' and 'Evangeline', respectively (Tables 2 and 3 ). However, the lack of response when harvest was delayed into November in Mississippi in 2010 (data not shown) and the LL combination in comparison with LE in Louisiana (Table 3) indicates that extending the harvest too late in the season is ineffective and possibly detrimental due to cold temperatures. EL marketable and jumbo grades were the top yields in both varieties regardless of year and location (Tables 2 and 3). These results reinforce the importance of getting transplants out as early as possible (Villordon et al., 2010). The increase in marketable yield as well as tonnage of larger roots produced by using the EL combination may significantly increase revenue for producers growing for both the fresh market as well as the processing sector.

This study demonstrated no loss in U.S. no.l yield by delaying harvest as long temperatures are adequate. The canner grade roots appear to have sized into U.S. no.l roots and the U.S. no.l roots into jumbo grade roots because no reduction was observed in U.S. no.l yield in Mississippi and Louisiana regardless of variety and year. In general, yield of Jumbo grade increased with early planting and late harvest, but not with late planting and late harvest in the season (Tables 2 and 3). An increased jumbo yield is especially valuable for the processing sector because it is available at a reduced price. Sweetpotato is indeterminate in growth and these results demonstrate that a longer growth period allows additional bulking without a compromise in the yield grade desired for fresh market. Thus, a producer targeting the fresh market can maintain their supply and realize a gain with a longer growing period by increasing their supply to the processing industry. This data implies little consequence in U.S. no.l yield if an unforeseen delay in harvest occurs as long as growing conditions are adequate; however, an extended delay (beyond adequate environmental conditions) may be risky and negatively affect the entire crop. Similarly, growing sweetpotato and delaying harvest in sweetpotato weevil-infested areas would be a risky business.

Plant Density. In-row plant spacing had a slight and inconsistent effect on canner yield only regardless of the variety (Tables 1 and 4 ). In 2010, 'Beauregard' responded with a higher canner yield at 12 inches than 16 inches in both states; however, there was no difference in 2011. 'Evangeline' canner yield was the same in Mississippi, but higher at 12 inches in Louisiana both years. Yield of U.S. no.l grade was reported to increase as plant spacing decreases to $15 \mathrm{~cm}$; however, differences were not pronounced for spacing between 31 and $38 \mathrm{~cm}$ (Schultheis et al., 1999). Higher canner yield were the only observed differences to plant spacing, yet the canner grade yield is the most inconsequential of all grades. Spacing at 16 or 20 inches appears to be a more advantageous spacing to adopt with 'Beauregard' and 'Evangeline' because reducing plant population per acre subsequently may reduce input costs. Similar to in-row plant spacing, only canner yield responded, also inconsistently, to changes in row width for both varieties (Table 5). Yield at 42 inches was higher than that at 38 inches in 2010 only. However, the canner grade is not considered a reliable tool in estimating the success of a crop. No additional differences were detected for any other category during 2010 or 2011. Therefore, the 42-inch row width may be recommended to decrease the number of plants per acre and maximize cost efficiency. In addition, the 
wider row width may have value in nonirrigated acreage, if water is a limiting resource.

ECONOMic ASSESSMENT. Changing plant density within the range tested in this study resulted in no changes in the economic benefit. Because the most valuable sweetpotato grades and gross income were not different among the plant densities (Tables 1, 4, and 5 ) and the variability in gross income was greater than the changes in costs that varied (data not presented), the net income was the same rendering no economic gain. In Mississippi, the most common planting distance is $42 \times 16$ inches, so increasing plant density would only increase planting cost without a gain in net benefit. However, in North Carolina reducing in-row plant spacing to 6 or 9 inches was reported to increase yield of 'Beauregard' U.S. no.l roots and the net economic value (Schultheis et al., 1999). Similarly, 'Beauregard' planted at 9 inches in Louisiana resulted in the highest yield of U.S. no.l when planted from mid-May to mid-June but no economic analysis was performed (Mulkey et al., 1994).

Delaying harvest time in early planted crop resulted in a net economic gain. Growers need to be cognizant of the market demands and adjust their practices accordingly to meet market expectations. Prices received by growers depend on the particular grade and market, and the difference in prices is a factor in the net benefit and marginal rate of return when delaying harvest (Table 6). The positive marginal rate of return indicates that for every additional dollar invested in delaying harvest, a proportional gain is attained and the net benefit of the crop is improved. On average, the increase in the estimated net benefit by delaying harvest $15 \mathrm{~d}$ in Louisiana was $\$ 634$ and $\$ 1377$ per acre for 'Beauregard' and 'Evangeline', respectively, when hand harvested for fresh market, and \$1187 and \$1589 per acre, respectively, when bulk harvested for processing after paying for all production and harvest costs (Table 6). The higher gain in net benefit and marginal rate of return of the bulk-harvest system for processing suggests that it has more room to improve than the hand-harvest system for fresh market. Similarly, the higher gain in net benefit and marginal return in 'Evangeline' suggests that the response was more sizable than 'Beauregard'. Therefore, delaying harvest is an important factor to take in consideration when maximizing yield for specific markets.

In summary, this study evaluated storage root yield in sweetpotato when delaying harvest at different plant spacing and row widths. Treatments were designed to increase overall tonnage and large roots and reduce costs. Results indicate that early planting and late harvest date combination results in increased tonnage, particularly of jumbo roots while maintaining the valuable U.S. no.l size roots. The increase in yield resulted in a gain in net benefit either for fresh market or for processing. This is important not only for producers growing strictly for a processor but for fresh market growers who intend to supply both the fresh market and the processing sector as well. Delaying harvest (as long as environmental conditions are favorable) to allow the crop to size did not negatively impact U.S. no.l productivity, but it does extend the time the crop is susceptible to flooding and frost damage. Altering plant spacing and row width did not increase yield in this study, and these practices may be determined by other factors in the grower's operation. Future research should examine fertility as well as irrigation requirements in varied production intervals to optimize total yield and the consequences to the various grades.

\section{Literature cited}

Boudreaux, J.M. 2012. Louisiana commercial vegetable production recommendations. Louisiana State Univ. Agr. Ctr. Publ. 2433. 2 Aug. 2013. <http://www.lsuagcenter. com/NR/rdonlyres/24293AEB-16484FBF-98EC-DA049238488A/59038/ pub2433commvegetableBWLOWRES. pdf>.

Carlson, H.L., K.M. Klonsky, and P. Livingston. 2008. Sample costs to produce potatoes (chippers for processing) 21 Oct. 2013. <http://coststudies.ucdavis. edu/current.php $>$.

Hood, K., D. Ingram, B. Layton, and D.H. Nagel. 2012. Traditional vegetables 2013 planning budgets. Mississippi State Univ., Dept. Agr. Econ. Budget Rpt. 2012-02. 21 Oct. 2013. <http://www. agecon.msstate.edu/whatwedo/budgets/ docs/MSUVEGl3.pdfs.
International Maize and Wheat Improvement Center. 1988. From agronomic data to farmer recommendations: An economics training manual (completely revised edition). Centro Internacional de Mejoramiento de Maíz y Trigo (CIMMYT), Mexico, DF.

Kemble, J.A., E.J. Sikora, D. Fields, M.G. Patterson, and E. Vinson. III. 2006. Guide to commercial sweetpotato production in Alabama. 2 Aug. 2013. <http://www.aces.edu/pubs/docs/A/ ANR-0982/ANR-0982.pdf>.

Loebenstein, G. and G. Thottappilly. 2009. The sweetpotato. Springer Verlag, Berlin, Germany.

Mulkey, W.A., W.B. McLemore, III, and T.P. Talbot. 1994. The effect of plant spacing on sweet potato varieties and promising seedlings. HortScience 29:726. (Abstr.).

Nalley, L., D. Hudson, and G. Parkhurst. 2005. Impact of taste, location of origin, and health information on market demand for sweetpotatoes. Mississippi State Univ. Mississippi Agr. For. Expt. Sta. Bul.1142. 2 Aug. 2013. <http://msucares. com/pubs/bulletins/bl142.pdfs.

Ravi, V. and P. Indira. 1999. Crop physiology of sweetpotato. Hort. Rev. 23: 277-338.

Reddy, K.R., B. Gajanayake, M. Shankle, and R.A. Arancibia. 2013. Temperature effects on sweetpotato growth and development. HortScience 48:S283. (Abstr.).

Rubatzky, V.E. and M. Yamaguchi. 1997. World vegetables: Principles, production, and nutritive values. 2nd ed. Chapman and Hall, New York.

Schultheis, J.R., K.A. Sorensen, D. Monks, G.J. Holmes, A.C. Thornton, and S.J. Toth, Jr. 2005. Crop profile for sweetpotatoes in North Carolina. 23 Oct. 2013. <http://www.ipmcenters.org/ cropprofiles/docs/ncsweetpotatoes. pdf $>$.

Schultheis, J.R., S.A. Walter, D.E. Adams, and E.A. Estes. 1999. In-row plant spacing and date of harvest of 'Beauregard' sweetpotato affect yield and return on investment. HortScience 34:1229-1233.

Stoddard, C.S., R.M. Davis, and M. Cantwell. 2013. Sweetpotato production in California. Univ. California Agr. Natural Resources Publ. 7237. 23 Oct. 2013. <http://anrcatalog.ucdavis.edu/ pdf/7237.pdfs.

Thompson, P., M. Williams, J. Byrd, J. Thomas, D. Parvin, and F. Killebrew. 2002. Commercial sweetpotato production in Mississippi. Mississippi State Univ. 


\section{Research Reports}

Ext. Serv. Publ. 1678. 2 Aug. 2013. <http://msucares.com/pubs/publications/ pl678.html $>$.

U.S. Department of Agriculture. 2005. United States standards for grades of sweetpotatoes. 7 Aug. 2013. <http:// www.ams.usda.gov/AMSvl.0/ getfile?dDocName=STELPRDC5050330 $>$.

U.S. Department of Agriculture. 2011. U.S. sweetpotato statistics-Table 25. U.S. sweet potatoes: Supply, utilization, and price, farm weight, 1970-2011.
2 Aug. 2013. <http://usda.mannlib.cornell. edu/MannUsda/viewDocumentInfo.do? documentID $=1492>$.

U.S. Department of Agriculture. 2013a. Crop production 2012 summary. 7 Aug. 2013. <http://usda01.library.cornell. edu/usda / current/CropProdSu / CropProdSu-01-11-2013.pdf>.

U.S. Department of Agriculture. 2013b. Crop values 2012 summary. 7 Aug. 2013. <http://usda0l.library.cornell.edu/ usda/current/CropValuSu/CropValuSu02-15-2013.pdf>.
Villordon, A., C. Clark, T. Smith, D. Ferrin, and D. Labonte. 2010. Combining linear regression and machine learning approaches to identify consensus variables related to optimum sweetpotato transplanting date. HortScience 45:684-686.

Woolfe, J.A. 1992. The contribution of sweetpotato and its products to human diets, p. 367-380. In W.A. Hill, C.K. Bonsi, and P.A. Loretan (eds.). Sweetpotato technology for the 21 st century. Tuskegee Univ. Press, Tuskegee, AL. 